特 集

\title{
ペタライト質耐熱陶器とその赤外線放射特性
}

\section{Petalite-Based Heat Resistant Ceramic Wares and Their Characteristic for Infrared Radiation}

\author{
橋本 典嗣 ${ }^{* 1}$, 谷口 弘明*1, 岡本 康男 ${ }^{* 2}$
}

\author{
Noritsugu HASHIMOTO, Hiroaki TANIGUCHI, Yasuo OKAMOTO
}

\begin{abstract}
Banko ware is famous for heat resistant ceramic wares such as earthen pot, ceramic plate and so on. Petalite is used as a raw material for these ceramic wares aiming for the enhancement of heat resistant property. Their thermal expansion coefficient is as low as $2.0 \times 10^{-6} \mathrm{~K}^{-1}$ due to $\beta$-spodumen produced from petalite during firing in the body. Heat resistant property is also improved because the porous body is suppressed the spreading for cracks. In addition, the infrared radiation of them is much higher than that of metal wares, which made it possible to heat ingredients efficiently. It is expected that Banko ware with heat resistant and high infrared radiation properties, which are advantages for a kitchenware, is used continuously at the kitchen in the future.
\end{abstract}

Keywords: heat resistance, ceramic ware, petalite, low thermal expansion, infrared radiation, emissivity.

(2019 年 12 月 20 日受付)

\section{1 はじめに}

茶碗や血などの日常雑器, さらには花器などの陶磁 器製の器は, 我々の生活に欠かすことのできない身近 な存在として, 日々の生活を彩っている。それらは食 卓で食事を盛りつけられる器としてだけでなく, キッ チンにおいて金属製の鍋やフライパンとともに者炊き や焼くといった調理にも用いられている。このような 直接火に掛けることのできる陶器は耐熱陶器と呼ばれ, 三重県四日市市を中心とする萬古焼がその主な産地と なっている。

萬古焼の歴史は江戸時代にまで遡り，沼波 弄山を その祖とする。2018 年には生誕 300 年を記念したイベ ントが開催されるなど, 今なおその歴史は続いている。 当時は色絵を施した器を特徵としていたが，現在は耐 熱陶器, 紫泥急須, さらには半磁器と呼ばれる食器な どが主要な製品となっている。而熱陶器としては，従 来からある土鍋や陶板に加え, 近年, 炊飯用土鍋やス キレット鍋も人気がある。萬古焼の土鍋はペタライト 質土鍋と呼ばれ，輸入された鉱石であるペタライトを 原料に用いている。この土鍋は, 1950 年代後半に三重 県四日市市の葖元が開発したものであり，ペタライト を用いることで低熱膨張を実現し，その結果，高い耐 連絡先： 橋本 典嗣， 广510-0805 四日市市東阿倉川 788, 三重県工業研究所窯業研究室,

e-mail: hashin02@pref.mie.lg.jp

*1 三重県工業研究所窯業研究室

*2 三重県工業研究所窯業研究室伊賀分室
熱衝撃性能を付与することに成功している。

ここでは，土鍋や陶板などのペタライト質而熱陶器 を中心に，セラミックス製の加熱調理器具の特徴や評 価方法について述べる。さらには，セラミックスの特 徵の 1 つである赤外線放射特性についても概説するこ とで，金属製の調理器具とは異なる而熱陶器の性質に ついて解説することとする。

\section{2 ペタライト質耐熱陶器}

\section{1 ペタライト質而熱陶器の特徵}

萬古焼として三重県四日市市を中心に生産される 土鍋や陶板のほとんどは, 原料にペタライト(葉長石, $\left.\mathrm{Li}_{2} \mathrm{O} \cdot \mathrm{Al}_{2} \mathrm{O}_{3} \cdot 8 \mathrm{SiO}_{2}\right)$ を用いたペタライト質である。代表

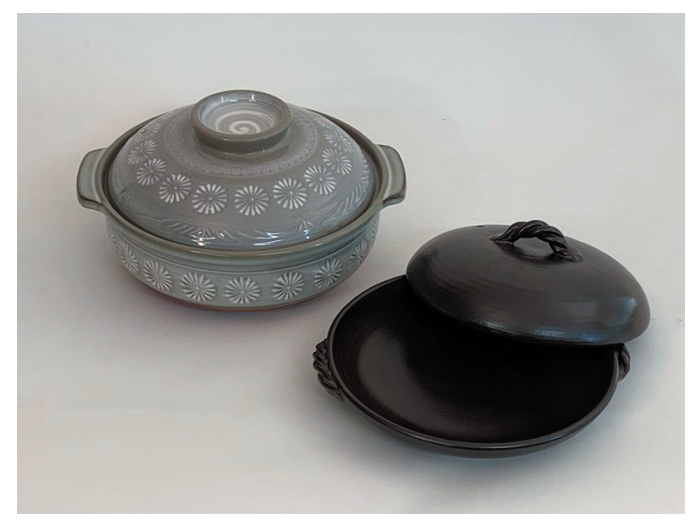

Fig. 1 Examples of petalite-based heat resistant ceramic wares made in Yokkaichi. 
的なペタライト質耐熱陶器である土鍋と陶板の一例を Fig. 1 に示寸。土鍋には伝統的な三島模様が施されて いる。

ペタライトはジンバブエ共和国から輸入した天然 の鉱石であり, 土鍋や陶板の素地に $40 \%$ 程度含まれて いる。残りの素地の組成は, 蛙目粘土や木節粘土など の可塑性粘土 $40 \%$ ，カオリンまたは口ウ石 $20 \%$ とい う簡単なものである $[1]$ 。これらを $1373 \mathrm{~K}$ 以上の温度 で焼成することで, $\beta$-スポジュメン固溶体

$\left(\mathrm{Li}_{2} \mathrm{O} \cdot \mathrm{Al}_{2} \mathrm{O}_{3} \cdot 4-10 \mathrm{SiO}_{2}\right)$ を生成させる。 $\beta$-スポジュメン 固溶体は, $\mathrm{SiO}_{2}$ の固溶量によって負の熱膨張を示寸[2] ことから,土鍋や陶板の熱膨張を下げることに寄与し, 一般的な土鍋の熱膨張係数は $2.0 \times 10^{-6} \mathrm{~K}^{-1}$ 程度と非常に 小さくなる。また，焼くといった調理に利用される陶 板では, さらに過酷な条件（空焚き）で用いられるこ とから, 熱膨張係数を $1.5 \times 10^{-6} \mathrm{~K}^{-1}$ 程度にまで下げるこ とが望ましい。

蛙目粘土一ペタライト系における素地中のペタラ イトの割合と熱膨張係数の関係を Fig. 2 に示す [3]。素 地中のペタライト量を増やすことによって熱膨張係数 は低下し，この系では，その量を $40 \%$ 以上とすること で熱膨張係数が $2.0 \times 10^{-6} \mathrm{~K}^{-1}$ を下回る。また, 焼成温度 を上げることによって, 熱膨張係数は大きくなってい くことも分かる。通常, 萬古焼では 1423 1453 K 程度 の比較的低い温度で焼成を行っており，この点からも 低熱膨張が期待できる。

また，これらの土鍋や陶板は陶器質であり，10\%以 上の吸水率をもつ多孔体である。素地中の孔は熱衝撃 を受けた際, クラックの伸展を防ぐことに寄与寸る。 さらに多孔体であることから，金属製の鍋に比べて熱

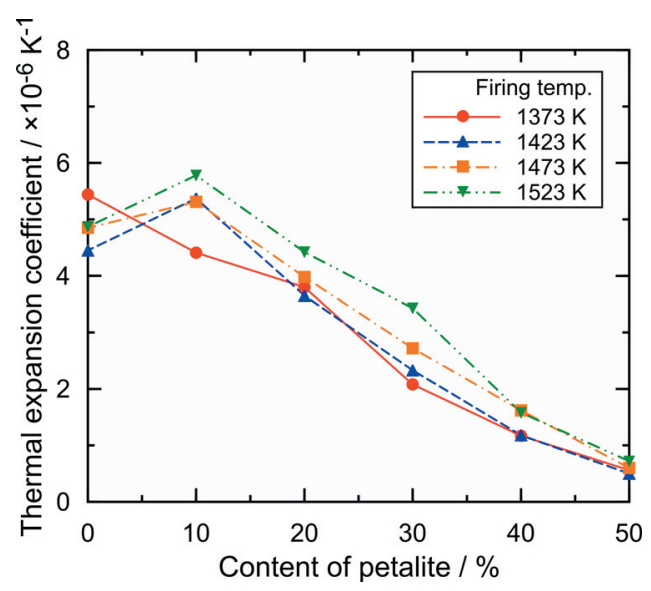

Fig. 2 Relationship between thermal expansion coefficient and content of petalite in the body.
伝導が小さく，温めたものが冷めにくいといった土鍋 特有の特徵にもつながる。

\section{2 而熱陶器の試験法}

日本産業規格によると陶磁器製耐熱食器は直火用 (高而熱), 直火用, 天火用 $\left(300^{\circ} \mathrm{C}\right.$ 以下), 天火用 $\left(200^{\circ} \mathrm{C}\right.$ 以下）の 4 種類に分類される[4]。ここで, 直火用は直 接火炎に当てて用いるもの, 天火用はオーブンなどの 直接火炎に当てない用途に用いるものとされている。 その中でも直火用（高耐熱）は急激な加熱及び冷却に 耐えるものとされており, 最も厳しい規格となってい る。

熱衝撃試験は水中急冷によって行われる。Table 1 に 日本産業規格で定められた，それぞれの種類に対する 試験温度差を示す。これらの温度差となるよう, あら かじめ加熱した恒温器の中に試料を 1 時間保持した後, ただちに水槽中 $\left(24 \pm 3^{\circ} \mathrm{C}\right)$ に投入し急冷する。試料が 水温まで泠えてから取り出し, 目視で釉層及び素地に 割れやき裂などの欠点がないか確認を行うことで, 而 熱衝撃性を判断する。

さらに, これらの耐熱陶器は食品衛生法 (昭和 22 年 法律 第 233 号) に基づく食品, 添加物などの規格基準 (有害物質の溶出基準) も満たす必要がある。

ペタライト質耐熱陶器であれば, この熱衝撃に関す る試験は難なくクリアすることが可能である。また萬 古焼では, 鉛, カドミウムが含有されているものを原 料として使用していないため, 食品衛生法で定められ た鉛，カドミウムの溶出試験も問題ない。実際の使用 に際しても，火に掛けて割れるといった事例はほとん じないものと思われる。なお, 而熱陶器についてさら に詳しく知りたい方は, 他の解説[5]を参照いただきた い。

Table 1 Temperature difference for heat resistance test.

\begin{tabular}{|c|c|}
\hline 種類 & 試験温度差 $/{ }^{\circ} \mathrm{C}$ \\
\hline 直火用 $($ 高耐熱 $)$ & $350 \sim 360$ \\
\hline 直火用 & $150 \sim 160$ \\
\hline 天火用 $\left(300^{\circ} \mathrm{C}\right.$ 以下 $)$ & $150 \sim 160$ \\
\hline 天火用 $\left(200^{\circ} \mathrm{C}\right.$ 以下 $)$ & $120 \sim 128$ \\
\hline
\end{tabular}




\section{3 赤外線を利用した加熱}

\section{1 物質への熱の伝わり方}

物質を効率的に加熱する方法として，赤外線の輻射 （放射）を利用する方法がある。一般にある物質から 他の物質への熱の伝搬には，対流，伝導，輻射の 3 つ の方法がある。対流は熱により物質周辺の空気などの 媒体が温められ, 熱エネルギーを保ったまま移動する ことで，被加熱物質に熱を伝える現象である。次に伝 導は物質同士の接触によって，温度が高い方から低い 方へと熱が直接的に伝わる現象である。この場合，接 触部分に急な温度上昇が生じることとなる。これに対 し，輻射は熱を伝える媒体がなくても，熱エネルギー は電磁波として被加熱物質に直接作用するため, 周囲 の媒体にエネルギーを奪われることなく効率的な加熱 を行うことができる。

\section{2 赤外線放射に関する基本的な法則}

\subsection{1 プランクの法則}

日本産業規格によると黒体は「入射した放射を，波 長，入射方向及び偏光状態に関係なくすべて吸収する 理想的な熱放射体」と定義されている[6]。この黒体か らの温度 $T$ における分光放射発散度 $E_{\lambda}$ は, 波長 $\lambda$ の関 数として, 次式のプランクの法則で表すことができる。

$$
E_{\lambda}=\frac{2 \pi h c^{2}}{\lambda^{5}} \frac{1}{\exp (c h / k \lambda T)-1}
$$

ここで, $h$ はプランク定数, $c$ は光の速度， $k$ はボルツ マン定数， $T$ は絶対温度である。この式を用いて計算 した 373〜 673 K における分光放射発散度を Fig. 3 に示

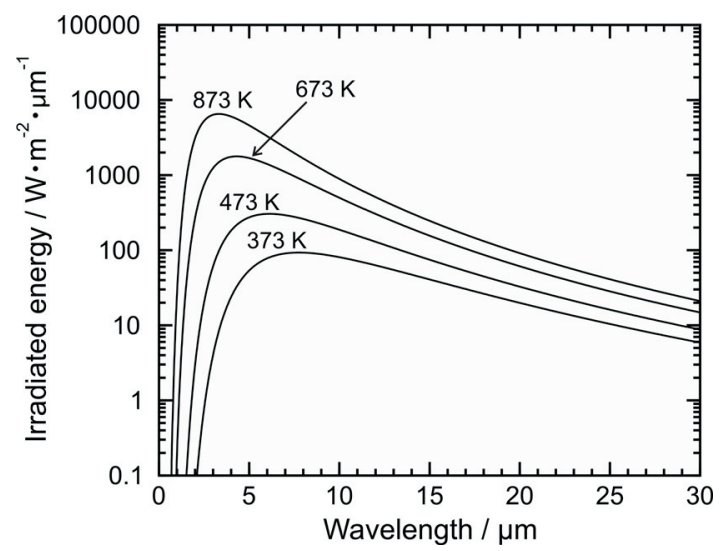

Fig. 3 Irradiated energy curves calculated using

Plank's low with 373, 473, 673 and 873 K of black body temperature.
す。この図から，分光放射発散度は温度の上昇ととも に大きくなっていくことが分かる。

\subsection{2 ウィーンの変位則}

プランクの法則から得られる黒体からの分光放射 発散度を微分し, 得られた結果が 0 となる波長から, 温度 $T$ と分光放射発散度が最大となる波長 $\lambda_{\text {max }}$ の関 係を得ることができる。

$$
\lambda_{\max }=\frac{2898}{T}
$$

この式はウィーンの変位則と呼ばれ， $\lambda_{\max }$ は温度が 高くなるにつれて低波長側にシフトしていくことを 表している。

\section{2 .3 ステファン・ボルツマンの法則}

温度 $T$ における黒体からの全放射エネルギー $E_{\mathrm{b}}$ は, 式(1)を全波長領域において積分することによって得 られ次式となる。この式はステファン・ボルツマンの 法則と呼ばれ，全放射エネルギーは絶対温度の 4 乗に 比例して大きくなることを示している。

$$
E_{\mathrm{b}}=\int_{0}^{\infty} E_{\lambda} d \lambda=\frac{2 \pi k^{4} T^{4}}{c^{2} h^{3}}\left(\frac{\pi^{4}}{15}\right) \equiv \sigma T^{4}
$$

ここで， $\sigma$ はステファン・ボルツマン定数である。

以上の 3 つの式から，赤外線放射は黒体の温度に大 きく依存することが分かる。特に全赤外線放射量は温 度の 4 乗に比例して大きくなるため, 赤外線の放射を 利用する場合，温度を上げればより大きな効果が得ら れるものと考えられる。

\section{3 赤外線放射率の測定方法}

物質からの赤外線放射率は，フーリエ変換赤外分光 分析装置(FT-IR)を用いて，加熱した試料から得られる 分光放射発散度を，黒体炉から得られるそれで割るこ とによって求めることができる。この際，測定時の光 路が同じ環境であれば，大気中の水分や炭酸ガスによ る吸収の影響も相殺されるため，結果にその影響が表 れることはほとんどない。

当所に設置されている赤外線放射率測定装置（島津 製作所製）の外観を Fig. 4 に示す。装置は黒体炉，試 料加熱炉, FT-IR, 検出器で構成されている。光学ミラ 一で光路を切り換えることによって, 温度一定の黒体 炬及び加熱した試料からの分光放射発散度が測定でき る。実際に測定する際には，黒体炉と試料表面の温度 を合わせる必要があるが，試料の表面温度を正確に測 


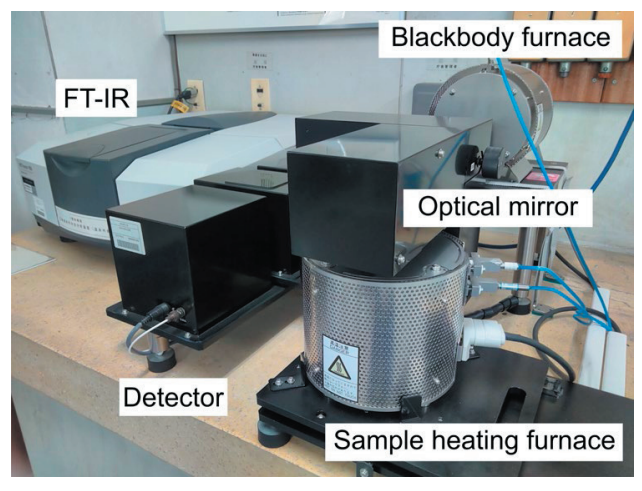

Fig. 4 Apparatus set-up for measuring the emissivity during infrared region using blackbody and FT-IR.

定することは困難である。当所では試料の表面温度を 保証するために，測定後の試料に黒体塗料を塗布し再 測定を行っている。黒体塗料を塗布した後の測定結果 から, 試料の表面温度を推定し, 必要に応じて測定結 果の補正を行う。なお，高温での分光放射率測定が可 能な機関は国内で数機関だけのようである[7]。

\section{4 赤外線放射の耐熱陶器への応用}

\section{1 セラミックスの赤外線放射の特徴}

セラミックスは，金属に比べ大きな赤外線放射を有 していることがよく知られている。そのため, 而熱陶 器は金属製のものにはない，赤外線放射の利用という 特有の機能が期待できる。Fig. 5 にアルミニウム, 酸化 アルミニウム (アルミナ), ペタライト質土鍋釉薬面の 分光赤外線放射率を示す。ここで，黒体炉は $673 \mathrm{~K}$ に 保持してある。この図から，金属であるアルミニウム の放射率は低く，一方，セラミックスであるアルミナ の放射率は波長によって大きく変動するものの，アル ミニウムに比べて非常に高い值を示すことが分かる。

このようにアルミニウムが酸化物（セラミックス） になることによって，その赤外線放射特性は大きく変 化する。さらにペタライト質土鍋の場合，その放射率 はさらに高くなり,多くの波長領域で $80 \%$ 以上を示す。 この特性は，ペタライト質土鍋などの耐熱陶器が，加 熱において赤外線放射を有効に利用できることを示唆 しており，優れた特徴の 1 つと言える。

次に各物質の分光赤外線放射率から計算した 2.5〜 $25 \mu \mathrm{m}$ における $373,673,873 \mathrm{~K}$ での積分放射率を Table 2 に示す。ここで積分放射率は, 分光放射率を用いて 計算から得られる試料の赤外線放射量を，黒体のそれ で割ったものである。陶磁器などの多成分から成るセ
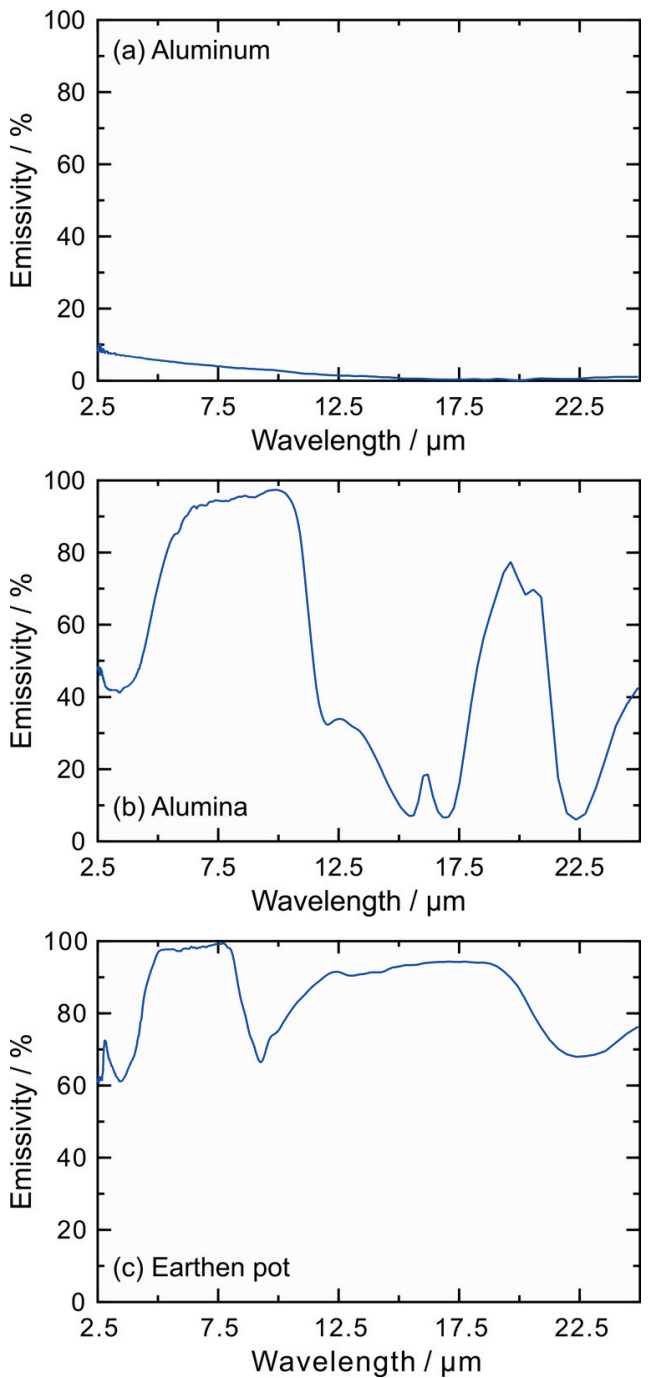

Fig. 5 Spectral emissivity in infrared region for (a) aluminum, (b) alumina and (c) earthen pot, respectively, measured at $673 \mathrm{~K}$.

ラミックスの多くは，75～90\%程度の積分放射率を示 す。一方,アルミナなどのファインセラミックスでは, その值が小さくなる。また，計算に用いた温度によっ ても積分放射率は変化する。これは，温度によって分 光放射発散度が変化(Fig. 3)するためである。すなわ

Table 2 Integral emissivity between 2.5 and $25 \mu \mathrm{m}$ for various materials calculated at 373,673 and $873 \mathrm{~K}$.

\begin{tabular}{|c|c|c|c|}
\hline \multirow{2}{*}{ Material } & \multicolumn{3}{|c|}{ Integral emissivity / \% } \\
\cline { 2 - 4 } & $373 \mathrm{~K}$ & $673 \mathrm{~K}$ & $873 \mathrm{~K}$ \\
\hline Aluminum & 2.7 & 4.6 & 5.4 \\
\hline Alumina & 63.9 & 67.2 & 63.3 \\
\hline Earthen pot & 87.9 & 85.2 & 81.9 \\
\hline
\end{tabular}


ち式(2)に示すステファン・ボルツマンの法則から決定 される $\lambda_{\max }$ 付近の放射率が高いと, 必然的に積分放射 率が大きくなる。

この表から，ペタライト質土鍋が高い積分放射率を 示すことが分かるが，計算に用いた温度を上げるとそ の值は小さくなる。これは, Fig. 5(c)に見られるように, 低波長領域の放射率が低くなっているためである。セ ラミックスのように温度による変質がない材料の場合, その温度範囲における分光放射率の変化はほとんどな い[8]。そのため, 使用する温度における $\lambda_{\text {max }}$ 付近で, 高い放射率を示すことが重要であり，このことが効率 的な加熱につながる。

しかしながら土鍋の場合，水を入れて著炊きに使用 するため, 赤外線放射は水に吸収され，水の加熱には 利用されるが, 直接具材を加熱することにはならない。 一方, 陶板などの焼き物調理用の耐熱陶器については, 伝熱による直接加熱に加えて, 赤外線放射による加熱 の効果も期待でき，さらには陶板の表面温度も高くな ることから赤外線放射の利用に適している。

\section{2 赤外線放射を利用した冷めにくい土鍋の開発}

2.1 節で述べたようにペタライト質耐熱陶器は多孔 質であることから，金属製のものに比べて冷めにくい 特徵がる。さらにこの特徵を生かすために, 土鍋の外 側の釉薬面に低赤外線放射材料を塗布した土鍋を作製 し，塗布していないものと比較を行った。その結果を Fig. 6 に示寸。なお，このときの低赤外線放射材料の $673 \mathrm{~K}$ における積分放射率は $4.1 \%$ ある。

この図から, 60 分後の水温に数 ${ }^{\circ} \mathrm{C}$ の差が見られ, 冷 めにくさに塗布の効果があることが分かった。これは 土鍋表面からの放射が抑制され，その分，熱エネルギ

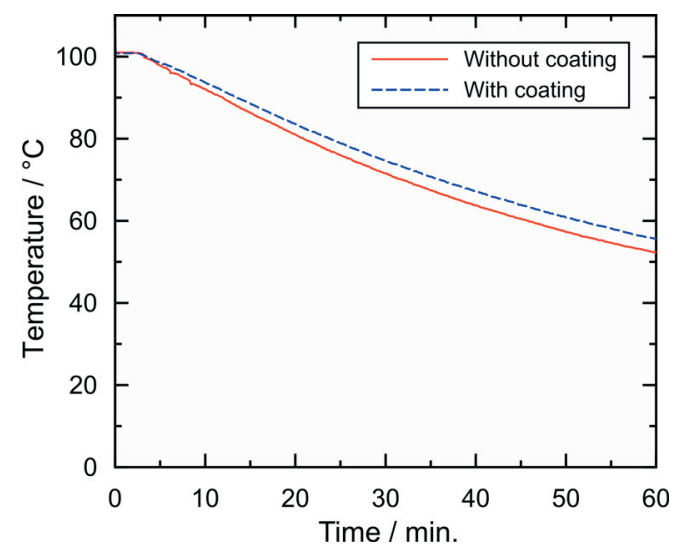

Fig. 6 Difference of water temperature in the earthen pot with and without low infrared radiation coating.
一を損失しなかったためであると考えられる。しかし ながら，この低放射性材料は金属光沢をもつものであ る。通常，釉薬はガラス質であるため，ガラス質でこ のような積分放射率をもつ材料を作製することは非常 に困難である。一方，金属光沢をもつものでは，土鍋 のもつ風合いが損なわれることから，釉薬のようなガ ラス質のもので，かつ低赤外線放射材料を開発するこ とが今後の課題である。

\section{5 まとめ}

三重県四日市市を中心に製造されている萬古焼は, 土鍋や陶板などの耐熱陶器を主力製品とする。これら の製品は原料としてペタライトを用いており，焼成す ることによって $\beta$-スポジュメン固溶体を生成させる。 この $\beta$-スポジュメン固溶体の存在によって, 加熱時の 熱膨張が小さくなり，その熱膨張係数は $2.0 \times 10^{-6} \mathrm{~K}^{-1}$ 程 度となる。また，セラミックス特有の優れた赤外線放 射特性を利用することによって，赤外線放射による効 率的な加熱を実現することができる。さらには，赤外 線放射を制御することで, 冷めにくいといった特徵も 付与寸ることが可能である。

このように，ペタライト質而熱陶器は機能面でも優 れた性質を示す。今後も萬古焼の器が食卓を彩るだけ でなく, 機能性調理器具としてキッチンで利用され続 けることを期待する。さらに，本稿がそのペタライト 質耐熱陶器を手にする 1 つの機会となれば幸いである。

\section{参考文献}

[1] 國枝勝利, 萬古・土鍋の製法, セラミックス, Vol. 29, No. 7, pp. 571-572, 1994.

[2] W. Ostertag, G. R. Fischer and J. P. Williams, J. Am. Ceram. Soc., Vol. 51, pp. 651-654, 1968.

[3] 伊藤隆, 西川孝, 榊谷幹雄, 蛙目粘土一ペタライト系 土鍋素地の開発，三重県科学技術振興センター工業研 究部 研究報告, No.32, pp. 24-30, 2008.

[4] 日本産業規格, 陶磁器製耐熱食器, JIS S 2400, 2000.

[5] 伊藤隆, 岡本康男, 新島聖治, 而熱陶器の技術動向, セラミックス, Vol. 52, No. 9, pp. 602-605, 2017.

[6] 日本産業規格，放射温度計の性能試験方法通則，JIS C 1612,2000

[7] 一般社団法人 遠赤外線協会, FAQ（測定機関）, http://www.enseki.or.jp/faq measure.php, (参照 2019-12-10).

[8] 高嶋廣夫，遠赤外線放射体の測定とその利用法，セラ ミックス, Vol. 24, No. 8, pp. 754-763, 1989. 